\title{
Land Use/Cover Changes between 1966 and 1996 in Chirokella Micro-watershed, Southeastern Ethiopia
}

\author{
Mohammed Assen* and Tassew Nigussie \\ Wollo University, P O Box 1271, Dessie, Ethiopia \\ Haramaya University, P O Box 138, Dire Dawa, Ethiopia
}

\begin{abstract}
Two periods of panchromatic aerial photographs taken in 1966 and 1996 were analyzed to determine spatial and temporal land cover changes occurring in Chirokella micro-watershed, Southeastern Ethiopia. The results of the analysis were digitized with Arc View GIS 3.3 software to produce land use/cover maps for 1966 and 1996. Five land use/cover categories, namely dense forest, moderately disturbed forest, bush, degraded and cultivated and settlement were identified. The result indicated an increase in an area of cultivated and settlement, bush and degraded and a decline in forest land cover categories over the 30 year period. The dense forest land cover decreased by over $80 \%$, giving an average decreasing rate of 32 ha $(-2.9 \%)$ per year. The moderately disturbed forest land was completely transformed to other land cover systems between 1966 and 1996. Cultivated and settlement land increased by $62.8 \%$, giving an annual average expansion rate of $33.3 \mathrm{ha}(+2.1 \%)$ over the analysis period. Bush and degraded land cover categories showed increasing patterns of $49.9 \%$ and $100 \%$, respectively. Transformation of forest land cover to others could explain an increasing demand for more arable and settlement land and timber resources associated with a population increase and a decline in land productivity due to degradation. This expansion largely took place onto steeper and upper slope positions, which resulted in increasing the area prone to land degradation, and further implicates adapting of more forest to cultivated and settlement land use/cover categories. Thus, it seems that, in the micro-watershed land, cover changes resulted from combinations of physical (e.g. land degradation) and socioeconomic (e.g. demand for more land resources) factors.
\end{abstract}

Keywords: Land Cover; Dynamic; Expansion; Exposed Land; Reduction

\section{Introduction}

In order to meet their demands, human beings engage in transformation of land cover systems. The form of transformation mainly involves a conversion of forest to agricultural and settlement land (FAO 2001). The pattern and magnitude of these transformations can be studied from an analysis of historical aerial photographs and satellite images (Solomon, 1994; Amare, 1996; Gete, 2000; Kebrom and Headlund, 2000; Muluneh, 2003; Selamyihun and Tekalign, 2003; Woldeamlak, 2003; Mohammed, 2006). This approach can help to inter about the past, and present as well as to predict future status of land (e.g. forest, soil and water) resources. It is used to evaluate potential land degradation, such as soil erosion occurring in response to land use/cover changes (Morgan, 1986).

With the help of satellite images organized by FAOUNDP, Daniel (1980) indicates that, before 1950s, natural forests covered nearly $40 \%$ of the highlands of Ethiopia. However, according to EFAP (1984), this extensive natural forest cover was reduced to $3 \%$ in the early 1980s. This estimate of forest cover was slightly raised to $4.5 \%$ in $1990 \mathrm{~s}$ and $4.2 \%$ in 2000 (FAO, 2001). The presence of differences in forest coverage of Ethiopia may partly suggest lack of accurate quantified data, at least at national levels. The slight increase in forest coverage of Ethiopia after 1980s may also partly imply the existence of some forest plantation activities in those periods. Irrespective of the presence of such differences and possible explanations, the historical decrease in forest cover could be attributed to the demand for additional space for cultivation, grazing, settlement and timber resources (EFAP, 1994; Gete,
2000; Kebrom and Headlund, 2000; FAO, 2001) and to a decrease in land productivity (Solomon, 1994). As indicated in some studies (Hurni, 1983; FAO, 1984), this situation has led to severe land degradation (e.g. soil erosion) in the country.

Local physical and socioeconomic characteristics of each locality determine land use/cover changes and its associated impacts. For instance, in the Metu area of Western Ethiopia, land cover changes involving cultivation following vegetation regeneration induces soil fertility decline (Solomon, 1994). In the south central highlands of Ethiopia, cultivated land expanded mainly onto steeper marginal parts by about $25 \%$ at the expense of forest land between 1957 and 1994 (Muluneh, 2003). In the Simen Mountains (Ethiopia), expansion of $12 \%$ to $41 \%$ of cultivated land onto high altitude forests was observed between 1975 and 1994 (Amare, 1996). In the Ginchi watershed of central west Ethiopia, cultivated land expanded by $118 \%$ and forest land decreased by $53 \%$ between 1957 and 1994 (Selamyihun and Tekalign, 2003). Whereas forest land decreased by $80 \%$, cultivated land increased by $55 \%$ in the Jelo micro-catchment of the Chercher highlands of Ethiopia between 1966 and 1996 (Mohammed, 2006). In parts of the north western highlands of Ethiopia, $98.9 \%$ of the forest land became cultivated land over 27 years (Gete, 2000). But in the other parts of north western highlands of Ethiopia, forest land increased by about 50\% between 1957 and 1998 due to mass reforestation programmes (Woldeamlak, 2003). Thus, analysis of land cover changes and patterns at local levels shows existence of spatial variability in effects, degree and extent of the problem. As a consequence, extent and degree of the problems need to be assessed within each of the micro-watershed conditions. As there 
is a link between upper and lower slope positions within a given watershed (e.g. in water flow, sediment and solutes movements), watersheds represent basis for understanding the state of land resources and form the basis of resource management unit. Therefore, management methods have to be designed to suit local conditions (Young, 1998).

For this reason, the objectives of this study are to assess the spatial-temporal patterns of land cover changes, quantify the rate and direction of these changes and indicate their significance to land degradation in the Chirokella micro-watershed. The study will create awareness among policy makers and extension workers in understanding the severity and extent of land cover changes and help to develop a natural resources management system in Chirokella micro-watershed as well as in the other parts of southeastern Ethiopia. The study watershed was selected partly because the area is one of the severely degraded parts of Ethiopia requiring involvement for proper land use plan and partly due to available aerial photographs at required scale for analysis. The authors assume that proper land use planning is necessary in the watershed and elsewhere in southeastern highlands, for which spatio-temporal information is required an a local scale.

\section{Description of the study area}

Chirokella micro-watershed is located between 08०59'50.3" - 09॰03'59.4"N and 40॰50'54.4" $40^{\circ} 54^{\prime} 45.2^{\prime \prime} \mathrm{E}$. It is found $4 \mathrm{~km}$ southeast of Asebe Teferi town, about $325 \mathrm{~km}$ east of Addis Ababa (Figure 1). It forms part of northern Chercher highlands, which are a part of the extensive highlands of Southeastern Ethiopia. Altitude of the micro-watershed ranges from 1800 meters above sea level ( $\mathrm{m}$ asl) to $3000 \mathrm{~m}$ asl. Slope degree ranges from less than 1 to over $50 \%$ and generally increases in a north-south direction. Based on data from Asebe Teferi, mean annual rainfall is $813 \mathrm{~mm}$ and the mean annual temperature is $20^{\circ} \mathrm{C}$.

The upper slopes mainly comprise mountains and hills and are covered with tertiary basaltic rocks, whereas the lower pediment slopes consist of colluvium-alluvium deposits. The watershed overlooks the Ethiopian Rift Valley system. The stream Chirokella (on which the study area is named) forms part of the Rift Valley drainage system of Ethiopia.

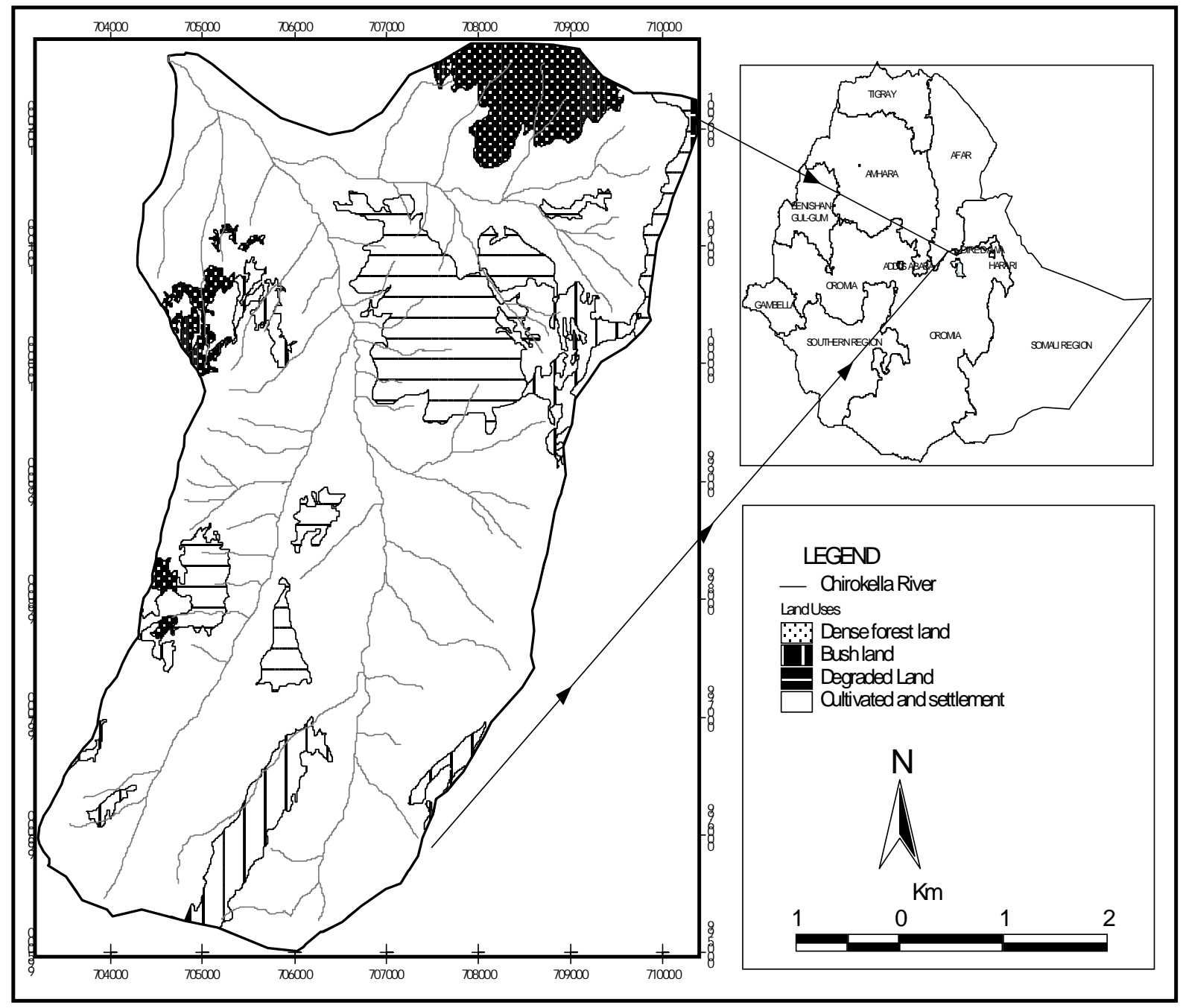

Figure 1. Chirokella micro-watershed, south eastern Ethiopia. 
The natural vegetation is dominated by Podocarpus fulcatus and Juniperus procera. These are found in the steeper and upper slope positions and in isolated stands in valleys. Sorghum (Sorghum bicolor (L.)) interspersed with maize (Zea mays) are the predominant cultivated food crops. Other minor cultivated food crops include potato (Solanum tuberosum), sweet potato (Ipomea batatas) and barley (Hordeum vulgare). Chat (Catha edulis) is the principal cash crop.

\section{Data Source and Analysis}

The required data for the study was acquired from interpretation of 1:50000 panchromatic aerial photographs taken in 1966 and 1996 obtained from EMA. As it was not possible to obtain other aerial photographs and satellite images are expensive, it was not possible to include other remote sensing data sources in the study. The available satellite images via World Wide Web were unsuitable for this study mainly for quality reasons

The boundary of the micro-watershed was delineated on a 1:50000 topographic map (EMA 1999) and then on the respective aerial photographs using mirror stereoscope. In the processing, interpretation, analysis and presentation of the results, computer assisted image interpretation software was used.

Aerial photographs used for the study were scanned with a resolution of 1200 dots per inch and stored in Tag Image File Format. To geo-reference the aerial photographs, a topographic map of the study area was scanned and registered with Universal Transfer Mercator
1983 metric projection. Important landmarks such as rivers, roads and the boundary used as a ground control point were digitized. Then, aerial photographs were georeferenced using different ground control points taken from topographic map with the help of the image analysis software. To have the required level of accuracy, georeferenced aerial photographs were further divided into four equal grid cells and geo-referenced again. This helps to reduce distortion and displacement which could exist primarily at the margin of aerial photographs. Then, the scanned watershed delineated on the aerial photographs was clipped on the delineated watershed of 1:50000 topomap. The recognized land use categories of the watershed on the aerial photographs were digitized in Arc View GIS 3.3. Analysis of transformations of one form of land use/ cover to others was made through overlaying the two sets of maps in the Arc View GIS 3.3 software environment.

Prior to analysis of the panchromatic aerial photographs, preliminary land use/cover categories were set and, in the course of interpretation, some classes were omitted whereas others were included. The accuracy of land cover classification was verified under field conditions in 2006. As it was difficult to separately delineate and map scattered rural settlement, this was included in the cultivated land. This seems to be logical as scattered homestead farms are planted in field crops. The land cover categories used in the final interpretation are given in Table 1.

Table 1. Description of categories of land cover in Chirokella micro-watershed, eastern Ethiopia.

\begin{tabular}{ll}
\hline Land cover category & Description \\
\hline Dense forest land & $\begin{array}{l}\text { Formed a portion of uncultivated land containing natural forest with nearly closed canopy } \\
\text { and undergrowth. }\end{array}$ \\
Moderately disturbed & $\begin{array}{l}\text { Uncultivated land containing scattered natural trees and secondary undergrowth. It } \\
\text { forest land }\end{array}$ \\
Bush land & Uncultivated land covered with open stand of trees and shrubs forming degraded part of \\
& forest land due to selective cutting of trees. It consisted of poor specimens of Podocarpus \\
& fulcatus. \\
This almost consisted of scattered scrubs and exposed bed rocks. Sporadically remnant big \\
Degraded land & trees were found only in gullies of this category. \\
Cultivated and & Land covered with annual and perennial crops and occupied by rural dwellings. Trees found \\
settlement land & around homesteads is also included in this category. \\
\hline
\end{tabular}

\section{Results and Discussion 3.1. Land Use/Cover Changes 3.1.1. Dense Forest Land}

Land cover under dense forest showed a considerable decline over the analysis period. In the study area, much of the forest cover was found on the steeper and upper slope positions of the landscape. In 1966, dense forest cover was 34\% (1117.3 ha.) of the area of the watershed, which was reduced to 5\% (162.8 ha.) in 1996 (Table 2; Figures 2 and 3). Between 1966 and 1996, dense forest cover decreased by $85.4 \%$. The average decrease was 32 ha. per year, giving an average annual deforestation rate of $2.9 \%$. This is an indicator of considerable transformation of dense forest land to other land cover categories. As a result, out of the 1966 dense forest land about $72.5 \%$ (809.7 ha) was changed to cultivated and settlement, $8.5 \%$ (94.4 ha) to bush and 6.1\% (67.8 ha) to degraded land categories. Thus, only 13.0\% (145.4 ha) of the 1966 dense forest land remained unchanged. This reveals that in Chirokella micro-watershed, forest removal for cultivation and settlement forms the major reason for its destruction. However, little transformation was made from other land covers to dense forest land category (Table 3). As a result, only about 17.4 ha of dense forest land was gained which, together with 145.4 ha retained from 1966, made a total of 162.8 ha. in 1996. 


\subsubsection{Moderately Disturbed Forest}

The moderately disturbed forest land covered 14.1\% (463.7 ha) in 1966, and was completely transformed to other land cover categories in 1996. It was transformed to degraded $(51.5 \%)$, cultivated and settlement (45.1\%) and bush $(2.1 \%)$ land cover categories. The relatively high percentage of transformation to degraded land reveals that, in 1966, much of moderately disturbed forest cover system was on the verge of destruction. The $45.1 \%$ transformation to cultivated and settlement land reconfirms the importance of clearing of uncultivated land for cultivation and settlement. It is also an indication of the presence of little rehabilitation and reforestation attempts in recovering forests during the 30 year analysis period.

Table 2. Land cover dynamics between 1966 and 1996 in Chirokella micro-watershed, eastern Ethiopia.

\begin{tabular}{|c|c|c|c|c|c|}
\hline \multirow[t]{3}{*}{ Land over class } & \multicolumn{4}{|l|}{ Year } & \multirow{3}{*}{$\begin{array}{l}\% \text { change between } 1966 \\
\text { and } 1996\end{array}$} \\
\hline & \multicolumn{2}{|l|}{1966} & \multicolumn{2}{|l|}{1996} & \\
\hline & (ha) & $\%$ & (ha) & $\%$ & \\
\hline Dense forest land & 1117.3 & 34 & 162.8 & 5.0 & -85.4 \\
\hline Moderately disturbed forest land & 463.7 & 14.1 & - & - & -100 \\
\hline Bush land & 118.7 & 3.6 & 177.9 & 5.4 & +49.9 \\
\hline Degraded land & - & - & 359.0 & 10.9 & +100 \\
\hline Cultivated and Settlement land & 1592.3 & 48.3 & 2592.3 & 78.7 & +62.8 \\
\hline Total & 3292.02 & 100 & 3292.02 & 100 & - \\
\hline
\end{tabular}

Table 3 Extent of land converted from each category to other land cover categories in Chirokella micro-watershed, eastern Ethiopia.

\begin{tabular}{|c|c|c|c|}
\hline Changed from & Changed to & Area (ha) & $(\%)$ \\
\hline \multirow[t]{4}{*}{ Dense forest land } & cultivated & 809.7 & 72.5 \\
\hline & bush & 94.4 & 8.5 \\
\hline & Degraded & 67.8 & 6.1 \\
\hline & unchanged & 145.4 & 13.01 \\
\hline \multirow[t]{5}{*}{ Moderately disturbed forest } & cultivated & 209 & 45.1 \\
\hline & bush & 9.7 & 2.1 \\
\hline & Degraded & 239 & 51.5 \\
\hline & Dense forest & 6.2 & 1.3 \\
\hline & unchanged & 0 & 0 \\
\hline \multirow[t]{4}{*}{ Bush land } & cultivated & 73.4 & 61.8 \\
\hline & Degraded & 2.5 & 2.1 \\
\hline & Dense forest & 1.1 & 0.9 \\
\hline & unchanged & 41.7 & 35.1 \\
\hline \multirow[t]{4}{*}{ Cultivated and settlement } & bush & 32.2 & 2.0 \\
\hline & Degraded & 49.8 & 3.2 \\
\hline & forest & 10.2 & 0.6 \\
\hline & unchanged & 1500.2 & 94.2 \\
\hline
\end{tabular}

\subsubsection{Bush Land}

The bush land category showed a slight increase from 3.6\% (118.7 ha.) in 1966 to 5.4\% (177.9 ha.) in 1996 of the area of the watershed. This reveals an increase in bush land category by $49.9 \%$ over the 30 year analysis period. The increase is gained from dense forest, moderately disturbed forest and cultivated and settlement land cover categories (Table 3). Much of the gain was from dense forest land, suggesting an existence of forest quality degradation in the micro-watershed. Bush land also transformed to cultivated and settlement (61.8\%), degraded $(2.1 \%)$ and dense forest $(0.9 \%)$ land cover categories. Hence, the high percentages of transformation to cultivated and settlement category reconfirms that, in a subsistence agricultural society, clearance of uncultivated land for cultivation and settlement represented the major reason for land cover changes.

\subsubsection{Degraded Land}

There was no identified degraded land category in 1966 following the employed classification criteria. But, on the 1996 aerial photographs, $10.9 \%$ (359.0 ha) of the microwatershed was classified in the degraded land cover category. This shows a 100\% increase in the degraded land category from 1966 to 1996. This was due to transformation of a part of other land cover categories to this land cover category (Table 3). Transformation to degraded land occurred from dense forest (6.1\%), moderately disturbed forest $(51.5 \%)$, bush $((2.1 \%)$ and cultivated and settlement (3.2\%) land use/cover categories. The high percentage of transformation of moderately disturbed forest to degraded land may be an indication of its intensive exploitation by the local community for construction and firewood purposes, suggesting that these may be some of the other reasons in 
(forest) land degradation in the micro-watershed. It also implicates that moderately disturbed forest category might have been at a critical stage of degradation on the 1966 aerial photographs and probably an absence of rehabilitation activities in the study area caused its degradation. A gain from forest land is also an indicator of the existence of severe degradation of dense forest land within the analysis period. The existence of isolated trees in gullies of degraded land (Table 1) means it was transformed from forest land via processes of deforestation.

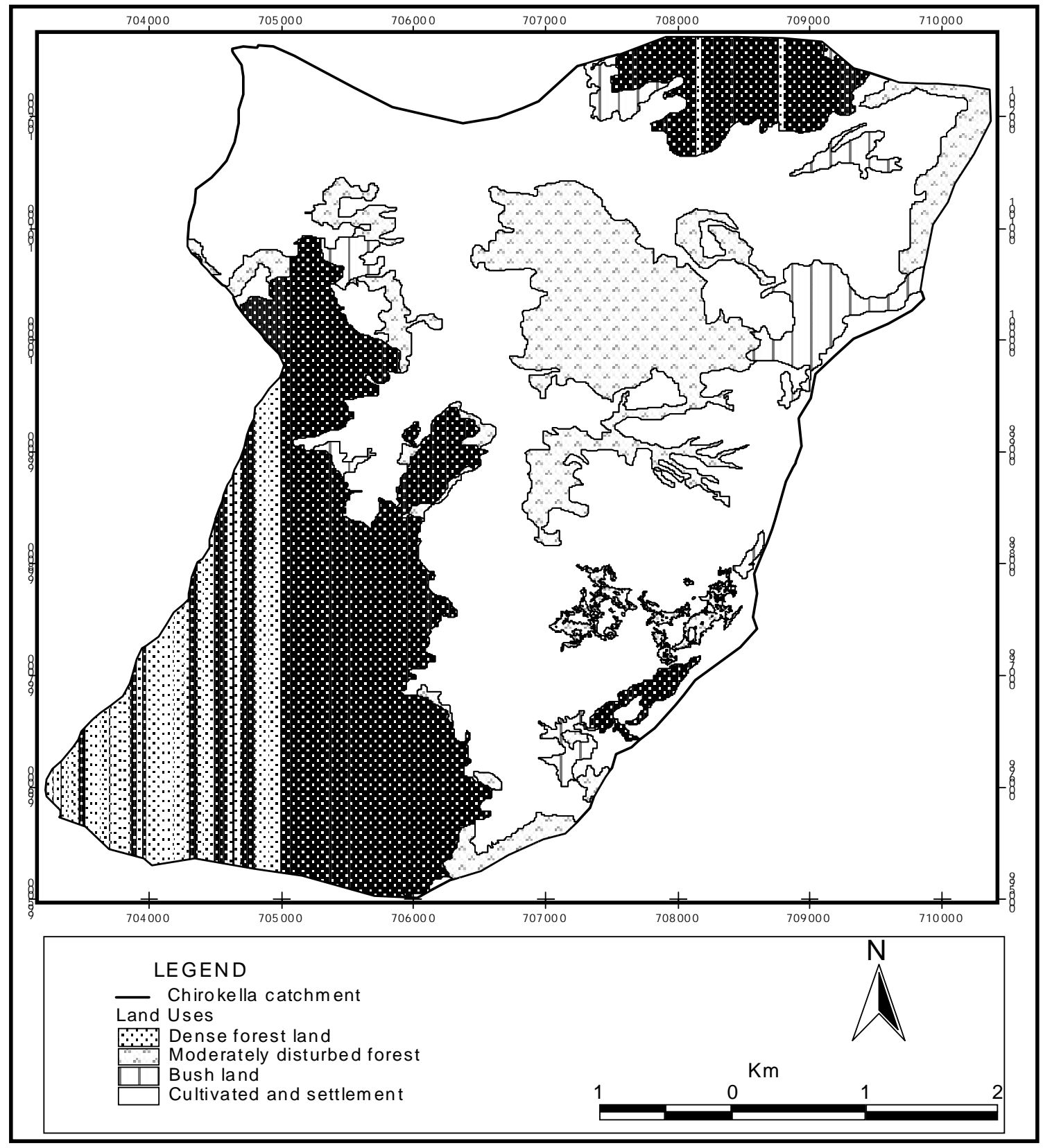

Figure 2. Land cover map of Chirokella Micro-watershed eastern Ethiopia in 1966.

\subsubsection{Cultivated and Settlement Land}

Considerable expansion of cultivated and settlement land was observed from 1966 to 1996. During the analysis period, this land cover category contained the largest portion of the study area. It contained $48.3 \%$ (1592.3 ha.) in 1966 and $78.7 \%$ (2592.3 ha.) in 1996 of the area of the micro-watershed. This showed a total increase of $62.8 \%$ between 1966 and 1996. The increase averaged to 33.3 ha/year, giving a rate of expansion of $+2.1 \%$ per year. Also, on the 1996 aerial photographs, isolated big remnants of local trees existed in some cultivated plots, suggesting recent transformation of forest to cultivated 
Mohammed and Tassew

land category in parts of those plots. This was verified in 2006 under field conditions. This expansion in cultivated and settlement land probably suggests that, in the microwatershed, food crop supply was achieved through farm land expansion rather than intensification. It may also implicate an existence of high population pressure with an increasing demand for more arable, settlement and timber resources. As discussed above, cultivated and settlement land encroached all non-cultivated land cover categories (Table 3). This land cover category also
East African Journal of Sciences Volume 3 (1) 1-8

showed a slight transformation to degraded (3.2\%), bush $(2.0 \%)$ and forest $(0.6 \%)$ land cover categories. Thus, much of the transformation is to degraded land and the least is to forest land. This reconfirms that, in the microwatershed, little effort has been made to rehabilitate the degraded land through reforestation programmes. Therefore, this study generally indicates a presence of a sequential change of forest to cultivated/settlement and, finally, to degraded land cover category.

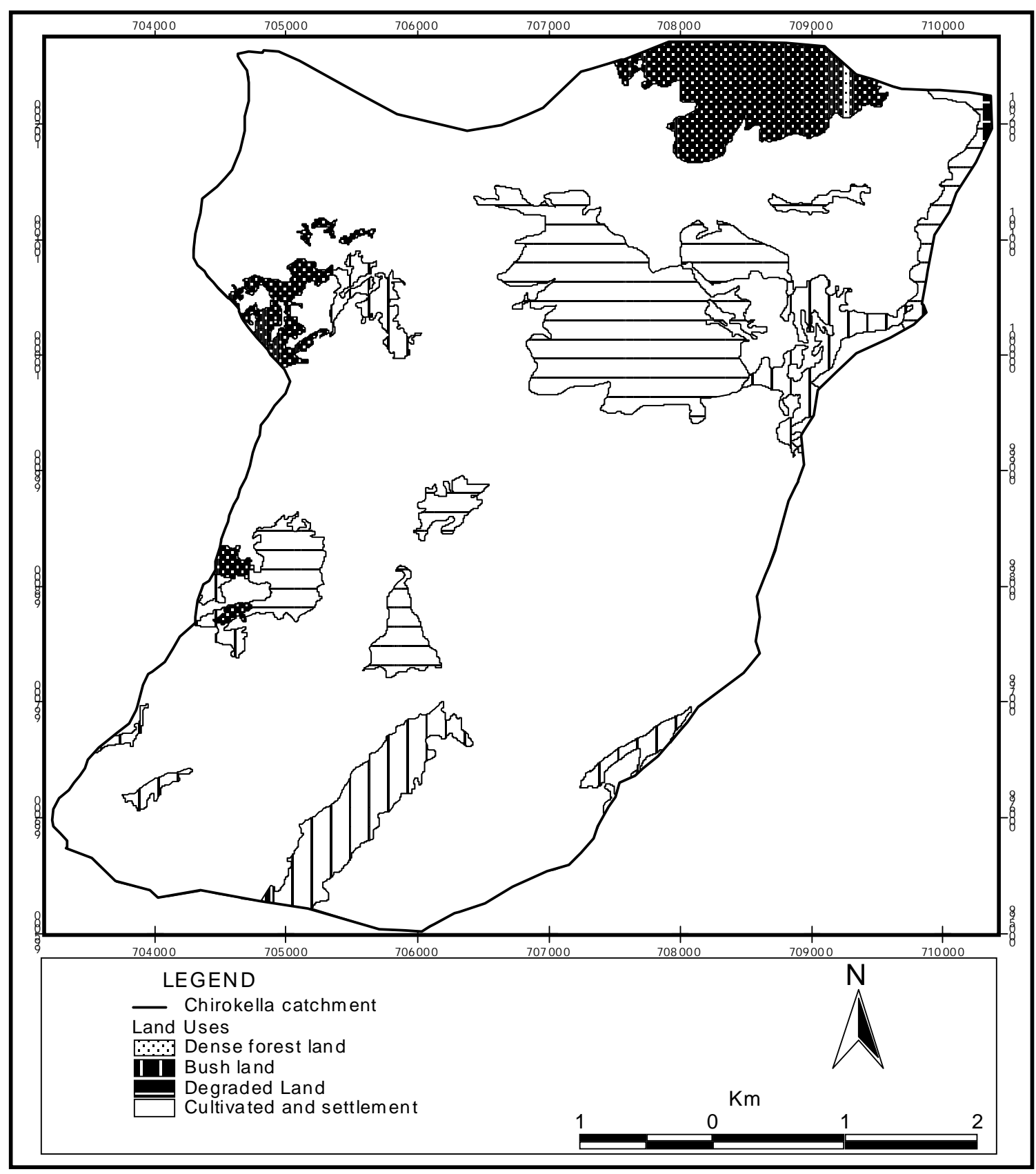

Figure 3. Land cover map of Chirokella Micro-watershed eastern Ethiopia in 1996. 


\subsection{Implications of Land Cover Changes to Land Degradation}

The removal of natural vegetation cover for various reasons as explained above could lead to land degradation, such as deforestation and soil erosion through land exposure to the impacts of raindrops. This process accelerates detachment and removal of soil particles and its associated consequences (Morgan, 1986). The problem becomes worse where steeper land is cultivated under intense seasonal rainfall (and high erosivity) in the absence of effective soil conservation measures (Belay, 1992), as in the Chirokella microwatershed. In Chercher highlands, among other factors, patterns of land cover and types of conservation measures form major determinants of rate of soil erosion (Thomas, 1998). As elsewhere in other parts of Ethiopia (Hurni, 1983; Barber, 1984; Constable, 1984), water erosion could form the dominant form of land degradation in Chirokella micro-watershed.

Considering the land cover status of the microwatershed, the degraded and cultivated and settlement land cover categories could be more vulnerable to processes of land degradation, such as soil erosion. As a consequence, the potential proportion of land prone to soil erosion increased from $48.3 \%$ in 1966 to $89.6 \%$ in 1996 of the total area of the micro-watershed. Therefore, on average, about 45.3 ha $(2.9 \%)$ of the 1966 degraded and cultivated and settlement land categories or $1.4 \%$ of the total area of the watershed was potentially exposed to soil erosion per year. This implicates that, in the study area, cultivated and degraded land cover systems would potentially form major sources of soil erosion. Therefore, the existence of spatial-temporal variability of potential environmental hazards (e.g. deforestation and soil erosion) in the Chirokella micro-watershed verifies the need for designing and implementation of land use planning and management methods suited to local site conditions.

\section{Conclusion}

Analysis of available panchromatic aerial photographs indicated that considerable land cover changes occurred in Chirokella micro-watershed between 1966 and 1996. The changes decreased the proportion of forest and increased the proportion of cultivated and settlement, bush and degraded land cover categories. Dense and moderately disturbed forest land categories decreased by over $85 \%$, whereas the other identified land cover systems increased from 50 to $100 \%$ over the 30 year period. Thus, a gain in the other land cover patterns is due to a loss in any form of forest cover. Over time, this could make the area prone to soil erosion as the land will lose its protective natural vegetation cover due to its removal for cultivation, settlement and other related purposes. The need for more land could explain the expansion in cultivated and settlement. It may also explain expansion of degraded land covers, as a result of forest resources consumption probably related to a growth in population size and/or a decline in land productivity in the micro-watershed. It appears that, through selective cutting of trees, dense forest land was sequentially changed to moderately disturbed forest land and then to bush land. Finally, it might have been converted to cultivated and/or settlement land, which may end up in degraded land. Thus, an interaction of physical (e.g. soil erosion) and socioeconomic characteristics (e.g. demand for more cultivated and settlement lands) has influenced to a great extent the patterns of land cover changes of the Chirokella microwatershed. Therefore, a sound watershed management plan is required in Chirokella micro-watershed as well as elsewhere in the Southeastern highlands. This could include reforestation of the degraded parts of the watershed, protecting and enhancing the existing forest land cover. Effective soil and water conservation and management methods that sustain improvement in productivity of the cultivated land could help in preventing expansion of forest to cultivation and marginal land cover patterns.

\section{References}

Amare, B. 1996. Land use changes, land cover changes and land use conflicts in the Simen Mountains National Park and its environs, North Gonder. MA Thesis, Addis Ababa University, Addis Ababa, Ethiopia.

Barber, R. 1984. Assessment of the dominant soil degradation processes in Ethiopian highlands: their impacts and hazards. Ethiopian Highlands Reclamation Study WP No. 23. Addis Ababa: Land Use Planning and Regulatory Department/Ministry of Agriculture.

Belay, T. 1992. Erosion: its effects on properties and productivity of Eutric Nitosols in Gununo area, Southern Ethiopia, and some techniques of its control. African Studies Series A9, University of Berne: Berne.

Constable, M. 1984. Degradation of resources and an evaluation of action to combat it draft of part II. Ethiopian Highlands Reclamation Study. Addis Ababa: Land Use Planning and Regulatory Department/Ministry of Agriculture.

Daniel, G. 1988. Environment and development in Ethiopia. In: Penros, A. (eds.) An Examination of the Issues Behind the Famine in Ethiopia. International Institute for Relief and Development, Food for the Hungry International. Geneva. pp. 55-96.

EFAP (Ethiopian Forestry Action Program). 1994. The Challenge for Development. Volume II. EFAP Secretariat: Addis Ababa, Ethiopia.

EMA (Ethiopian Mapping Authority). 1999. Map Series ETH 4 (sheet 0940 D4). Addis Ababa: EMA.

FAO (Food and Agriculture Organization of the United Nations). 1984. Land use, production regions, and farming systems: Assistance to land use planning. Technical report No. 3. FAO: Rome.

FAO (Food and Agriculture Organization of the United Nations). 2001. Global forest resources assessment 2000 main report. FAO forestry paper 140. FAO, Rome.

Gete, Z. 2000. Landscape changes and soil erosion process modelling in the North-Western Ethiopian 
highlands. African Studies Series A16, University of Berne: Berne.

Hurni, H. 1983. Soil erosion and soil formation in agricultural ecosystems: Ethiopia and Northern Thailand. Mountain Research and Development 3(2): 131142.

Kebrom, T. and Headlund, L. 2000. Land cover changes between 1958 and 1986 in Kalu district, Southern Wello, Ethiopia. Mountain Research and Development 20(1):42-51.

Mohammed, A. 2006. Land use/cover changes over a period of three decades in Jelo Micro-catchment, Chercher highlands, Ethiopia. Ethiopian Journal of Natural Resources 8(1):39-56.

Morgan, R P C. 1986. Soil Erosion and Conservation. 2 ${ }^{\text {nd }}$ edition. Longman: New York.

Muluneh, W. 2003. Impacts of population pressure on land use/land cover change, agricultural system and income diversification in West Guraghe land, Ethiopia.
Norwegian University of Science and Technology (NTNU): Trondheim.

Selamyihun, K. and Tekalign, M. 2003. Land use changes and erosion on some highland soils of Ethiopia. Ethiopian Journal of Natural Resources 5(2):215-231.

Solomon, A. 1994. Land use changes, soil degradation and potential for sustainable use in Metu area, Illubabor region, Ethiopia. African Studies Series A13, University of Berne: Berne.

Thomas, T. 1998. Result of soil conservation experiments and the scope for implementation: the case of Chercher highlands. Ethiopian Journal of Development Research 20(2):25-64.

Woldeamlak, B. 2003. Towards integrated watershed management in highland Ethiopia: The Chemoga watershed case study. $\mathrm{PhD}$ Thesis. Wageningen University and Research Centre, Wageningen, The Nether Lands.

Young, A. 1998. Land Resources: Now and for the Future. Cambridge University Press: Cambridge. 